\title{
JESUÍTAS E ÍNDIOS NA SOCIEDADE MISSIONEIRA: UMA ANÁLISE CRÍTICA DA HISTORIOGRAFIA
}

\author{
Maria Cristina dos Santos*
}

\section{Introduçāo}

O presente estudo tem por tema a investigação dos aspectos sociais dos povoados missioneiros, através da seleção e crítica de algumas obras produzidas pela historiografia do Rio Grande do Sul. As obras analisadas são Porandúba Rio Grandense de autoria do historiador jesuíta Pe. Teschauer, Capitania d'El Rei de Moyses Vellinho e $O$ Socialismo Missioneiro de Décio Freitas. A escolhadas obras se deu em função da proposta de crítica historiográfica e a partir daí realizou-se o levantamento do aspecto social.

Por ser o "aspecto social" algo generalizante e pouco preciso, já nas suas raízes sociológicas, o termo é utilizado normalmente de forma global, sem maiores especificações. Isto significa que não se encontrou, nas obras analisadas, descriçōes claras e detalhadas sobre a organização e estrutura social dos povoados missioneiros. Ou por outra, freqüentemente os autores utilzam-se de expressões como "organização social", "formação social", ou mesmo "aspecto social" para descrever a articulação do sistema político e econômico em relação à sociedade. Ou seja, sem descreverem como se forma esta sociedade, utilizam-na para comprovar teses pré-concebidas sobre o sistema geo-político e econômico das Reduções. Neste quadro, é interessante observar que, nas colocaçöes dos autores estudados, prevalecem a habilidade do discurso e o maniqueísmo das interpretaçōes, pois muitas vezes os argumentos e as qualificaçōes utiliza- 
das são tão contraditórios que não parecem referir-se ao mesmo objeto de estudo. A partir de como os autores vêem os aspectos de estrutura e organização social, se elabora a problemática que guiará este estudo.

Uma vez que esta pesquisa se prende mais à análise conceitual e à crítica das construçōes teóricas daí resultantes, se torna necessário esclarecer que entende-se por estrutura social a formação da sociedade a partir da composição e atuação dos diversos grupos presentes na sociedade missioneira. À organização social reserva-se o sistema de relaçöes que se estabelece entre os membros dos grupos e dos grupos entre si, bem como as variáveis que interferem nestas relaçöes. Assim, os indivíduos reunidos num povoado formam a base da sociedade, e as relaçöes, que se estabelecem entre eles, constituem o aspecto dinâmico da organização desta sociedade. ${ }^{1}$ $\hat{E}$, portanto, através da análise do tratamento de dois grupos básicos, jesuítas e indígenas e a articulação destes no sistema missioneiro, que se procura decantar as posições dos autores no que se refere ao aspecto social dos Povoados Missioneiros.

Pretende-se, desta forma, levantar as diversas posiçöes existentes na historiografia sobre a caracterização do indígena, enquanto elemento base sobre o qual se constrói esta sociedade; o papel dos jesuítas a estes indígenas e a participação da Companhia de Jesus no sistema colonial ibero-americano. Neste levantamento, enfatiza-se as construçōes teóricas e as argumentaçōes factuais utilizada pelos autores. Nảo é objetivo alcançar uma verdade reveladora, ou realizar uma análise abrangente, mas sim demonstrar as possibilidades de reconstrução histórica do passado. $O$ objetivo maior deste estudo será demonstrar, através do discuso, o quanto estas reconstruções se afastam daquilo que é conhecido do passado, ao mesmo tempo em que se aproximam das elaborações e aspirações pessoais de quem as escreveu.

O cunho idealista, presente nas obras analisadas, se dá em função de que os autores pretenderem abordar a "totalidade" do processo histórico missioneiro, sem considerar a complexidade que envolve a análise e muito menos os "limites e possibilidades" que se impōem na tarefa de reconstrução do passado. ${ }^{2}$ Nas idealizaçōes arbitrárias estāo implícitas a parcialidade e a passionalidade dos autores; que, embora compreensíveis, poderiam ser minorados pela utilização de recursos teóricos-metodológicos compatíveis com os aspectos analisados. 
Assim, temos, na análise das obras selecionadas, um perfil de vários dos problemas que atingem a produção historiográfica sobre Missões. Num primeiro momento, a obra do historiador Carlos Teschauer reflete a passionalidade e o subjetivismo de argumentos destinados a salvar a Companhia de Jesus de acusaçôes de seus adversários. As afirmações do autor em função da polêmica (pró-contra Companhia de Jesus) possuem uma limitada objetividade. Num discurso etnocentrista, o Autor encaminha-se para uma históriatribunal e não oferece conclusões historicamente comprovadas.

Depois, na análise sobre a obra de Moyses Vellinho, verifica-se a continuidade da discussão polêmica e não da reconstituição histórica. Elaborando uma história dirigida, nacionalista e exaltadora dos bandeirantes, o Autor busca integrar o Rio Grande do Sul na área de domínio da Coroa Portuguesa; rotulando a área de Missōes (Sete Povos) como parte de um Império Ameaçador. Para isto, seleciona enfoques que reforcem seu ponto de vista, distorce aqueles que não se encaixam e desconsidera as informaçöes contidas nas fontes escritas.

No terceiro momento se analisa a obra de Décio Freitas e comprova-se o maior número de arbitrariedades possíveis sob o aspecto teórico-metodológico. Numa visão essencialista, privilegia uma parte do sistema econômico missioneiro e procura enquadrá-lo nas categorias do materialismo histórico, confirmando, assim, a existência dos princípios socialistas naquela sociedade. "O mito da totalidade repousa justamente neste caráter essencialista da análise, ou seja, no aspecto metafísico da questão". ${ }^{3}$

Assim as tentativas dos autores não ultrapassam o grau de elaboraçōes mentais com mais ou com menos comprovação factual; com mais ou com menos objetividade, e, a maioria, sem nenhuma preocupação metodológica e pertinência teórica. Conforme os aspectos apontados por Amo Kern, se percebe a distância existente entre as elaborações mentais apresentadas e a reconstrução histórica.

"A reconstituição histórica deverá ser objetiva de maneira que possamos resolver a contento a problemática que deu início à pesquisa, sem que se inverta à luz da imaginação não científica uma história que, gostaríamos, fosse verdadeira. $\mathrm{O}$ que é verdadeiro na reconstituição histórica e relativo aos dados consultados nem sempre coincide com nossas hipóteses iniciais. E se nossas hipóteses iniciais forem plenamente confirma- 
das, é necessário testar novamente a metodologia; pois talvez tenhamos selecionado os dados de maneira a coincidir com os preconceitos iniciais." 4

Somente ao realizar uma abordagem criteriosa a nível teóricometodológico, multi-variável e inter-disciplinar, é que se tem noção de quantos problemas ainda ficam sem solução e de quanto os resultados encontrados säo relativos, pois do contrário com um raciocínio unilateral e mecanicista, as respostas já estão prontas, dispensando, por vezes, a própria pesquisa.

\section{I - O indio visto pelo jesuíta}

Esta primeira parte da análise tem a proposta de mostrar a visão e a posição do jesuíta frente ao indígena. Utiliza-se, para este estudo, uma obra do historiador Carlos Teschauer, membro da Sociedade de Jesus. Em 1929, foi publicado uma série de ensaios e estudos do referido autor, sob o nome de Porandúba Riograndense, da qual utilizamos três capítulos. ${ }^{5}$ Como é uma coletânea, reúne textos de vários assuntos, principalmente dados etnográficos sobre as populações indígenas e aspectos da história do Rio Grande do Sul.

Partindo da ocupação pré-histórica do atual Rio Grande do Sul, o Autor busca, através da narrativa da ação da Companhia de Jesus neste território, demonstrar as dificuldades político-administrativas e religiosas enfrentadas pelos missionários. Procura, sobretudo, enfatizar o despreendimento e os esforços destes homens para a conversão dos neófitos. Nos capítulos analisados, seu objetivo maior é engrandecer a obra e os propósitos da Companhia de Jesus, ao mesmo tempo em que procura responder e resguardá-la de acusaçöes recebidas por adversários das atitudes de seus membros, durante a obra de catequização.

\section{1 - O PAPEL DA COMPANHIA DE JESUS}

A princípio, Teschauer faz questão de salientar as relações de inter-dependência entre as Missōes e o poder secular e temporal, bem como ressaltar o papel de instituiçōes partícipes do sistema colonial. Ao comentar que o poder dos missionários estava limitado, 
por um lado, pelas instituiçōes político-administrativas espanholas a serviço do monarca, e, por outro lado, que deviam obediência às autoridades religiosas locais e ao papado; o Autor pretende mostrar que os jesuítas não agiam nem tomavam decisōes por conta própria.

\begin{abstract}
"Naquella época o Rio Grande do Sul fazia parte do domínio hespanhol e do govemo civil e ecclesiastico de Buenos Aires (...) Os missionários (...) estavam sujeitos directamente á jurisdição papal, exercendo todos os ministerios sem depender de outra autoridade ecclesiastica, sinão do seu superior regular." 6
\end{abstract}

Sem dúvida, as afirmações do autor são procedentes, uma vez que as Missões não se constituiam em unidades isoladas de todo o sistema colonial hispano-americano. O Autor parece ter, bem claro, a "teia de relaçōes" que liga os povoados ao sistema político e à hierarquia relgiosa das colônias. Aliás, quanto às colocações do complexo processo político-administrativo que envolve as Missōes, o Autor apresenta afirmaçōes coerentes e embasadas.

A partir do momento em que se propöe a defender a Ordem e seus membros de acusações, que até então não haviam encontrado "refutação satisfactoria", o Autor passa a uma elaboração subjetiva e, freqüentemente, contraditória. O discurso de Teschauer, sobre a ação da Companhia de Jesus, tem um objetivo claro e definido: demonstrando as dificuldades que os jesuítas encontraram para converter os "selvagens" do Rio Grande do Sul "primitivo", pretende justificar a importância da ação da Companhia de Jesus, salientando os impedimentos "naturais" de se esperar resulados positivos de uma empresa tão arriscada.

O pioneirismo dos membros da Companhia de Jesus, no conhecimento da região, é um fato inegável, até mesmo para os “adversários” dos jesuítas. Entretanto, o mérito maior é quanto ao papel real a que se dispunha a Companhia de Jesus em meio aos selvagens, ou seja, a "conquista espiritual" para a "redução" e a partir daí a civilização. Catequisar e civilizar os indígenas implica numa transformação radical e irremediável para o modo da vida das sociedades tribais. ${ }^{7}$ Uma missãó tão ampla possui justificativas (em sua maioria etnocêntricas) para todas as atitudes encetadas pelos missionários, e até mesmo para aqueles objetivos näo alcançados. 
Conforme Meliá, esta profunda transformação já estava implícita no momento em que Montoya elaborou o conceito de "Redução", onde consta "reduziu-os a diligência dos padres a povoaçōes não pequenas à vida política (civilizada) e humana". ${ }^{8}$

Este processo de transformações se torna tanto mais difícil, pela situação em que os "diligentes padres" encontram os selvagens. A partir das descriçōes do autor sobre as condiçōes dos indígenas, percebe-se um gradual enaltecimento dos missionários.

"Os povos bárbaros tem ainda suas leis, suas autoridades que os governam, tem sua agricultura, e até mesmo certa indústria, são de alguma sorte policiados e entretem relaçōes amigáveis com as nações que lhe são visinhas. Nada disto têem, por via de regra, os selvagens." 9

Partindo deste substrato cultural tão acanhado, cresce ainda mais a obra de evangelização e civilização a cargo dos jesuítas. $\mathrm{O}$ etnocentrismo desta visão gera uma série de conclusões a nível cultural, econômico e social, que os jesuítąs adotam como verdades absolutas e que é seu mister transformar. Em relaçảo à economia indígena, por exemplo, o jesuíta utiliza-se da comparação com as formigas, feita por um "autorisado escriptor":

"estes selvagens para se sustentar, e, menos civilisados que as formigas, nâo faziam provisão alguma para o inverno, gastando cada dia tudo quanto tinham."10

A bem đa verdade, não se poderia exigir que, na década de 1920 , o Autor tivesse grandes e profundos conhecimentos antropológicos sobre o sistema de vida das sociedades tribais. Embora, nesta mesma obra, o Autor trace um retrospecto etnográfico e lingüístico dos grupos indígenas que habitavam a porção meridional do Brasil, ressaltando alguns aspectos como costumes, tradiçōes, organização e relaçöes sociais e, principalmente, o papel da língua neste contexto. As informações apresentadas pelo autor, sobre o grau de desenvolvimento cultural dos guaranis, contradizem as depreciaçöes feitas agora em relação aos indígenas. Teschauer ocupa vários capítulos da obra para demonstrar quanto os jesuítas compreenderam e respeitaram os costumes indígenas, uma vez que procuram não transformar sua língua original e sim adaptar-se a ela. Portanto, para o Autor. 
"Os Missionarios applicaram todos os meios a seu
alcance para formar homens independentes, civilisados,
individualidades capazes de agir por si; porém as cir-
cunstâncias os impediram de executar completamente
seu plano, e, por conseguinte, os adversários lhes ex-
probaram por não terem alcançado aquillo que se cons-
titue simplesmente uma impossibilidade aos olhos de
qualquer juíz imparcial."

Mais do que demonstrar o despreendimento e os esforços dos missionários, o Autor utiliza-se desta afirmação também para negar as duas gravez acusações feitas aos jesuítas e sua obra evangelizadora. São elas:

1. ) "Por seu systema de civilisar e catequisar os índios, os Missionários S.J. destruiram neles a personalidade degradando-os ao estado de meros automatos.

$2^{\circ}$ ) "Os padres S.J. suffocaram a individualidade entre os Bugres, não os ensinando a fundarem seu proprio lar, mas a viverem em comunismo". 12

Antes de se comentar como o Autor procurou defender os missionários de tais acusaçōes; cabe dizer que, para a proposta de ameaçar a obra da Companhia de Jesus, as acusações foram muito mal formuladas.

Em momentos anteriores da obra, o Autor já havia demonstrado um razoável conhecimento histórico e etnográfico sobre os indígenas com os quais os jesuítas travaram contato. Mas, no momento da "defesa", parece ter privilegiado os argumentos subjetivos e passionais, em detrimento das factuais que poderia demonstrar; caindo em contradição com seu próprio discurso.

Teschauer responde a estas acusaçöes de três formas: primeiro, utilizando-se do estado selvagem dos indígenas, concluindo, portanto, que os progressos conseguidos demonstram o esforço e desprendimento dos missionários. Depois, faz uma avaliação dos motivos que impediram de alcançar sucesso em todos os esforços e, por último, reforça mais uma vez que os progressos conseguidos foram imensos, também pelas circunstâncias históricas que impediram seu maior desenvolvimento. ${ }^{13}$ Cabe salientar que a argumentação e as justificativas apresentadas recaem sempre na demonstração da fraqueza e inapetência dos indígenas. 
Quanto à aniquilação da personalidade, coloca que existem duas formas; a direta praticada pelos colonos através da escravidão, e a indireta que consistiria em nâo induzir nem incitar os atos de iniciativa própria. Entre estas duas formas, qual a praticada pelos missionários? Nenhuma. Simplesmente porque os padres exerciam uma "autoridade suave e paternal" sobre os neófitos; e também porque estar sujeito à obediência näo prejudica a personalidade, pois sem sujeição não há a verdadeira liberdade."14 Mas, o Autor não admite a aniquilação da personalidade do índio, sobretudo porque este não possui substrato para ser aniquilado.

“ $O$ índio não tem capacidade intelectual para aspiraçōes maiores, nem o pretende, nem o deseja. Os PP. tem o encargo de lhes ensinar tudo e induzil-os a agir contra seu genio."15

O que realmente a ação civilizatória pretende é elaborar ou criar a personalidade e a mentalidade econômica e política européia, tanto quanto a cristianização tem como objetivo apagar todo os fundamentos culturais e tradicionais dos indígenas. Utilizando dos exemplos das instituições criadas pelos jesuítas em cada Povoado (cabildo, Tupambaé, Amambaé), o Autor coloca claramente a proposta civilizatória dos Missionários.

"Pergunto aqui ao leitor si quem falla assim e mais si quem agem assim, como estes missionários, teve vontade de suffocar a personalidade dos índios ou si, pelo contranio, nâo almejava e agia com todas as véras de sua alma, para atingir, como um fim suspirado, o excitar e fazer nascer esta personalidade e iniciativa dos índios?"'16

Parece nảo serem necessárias mais demonstrações de quanto o discurso do historiador jesuíta distorceu o modo de vida e os padrões culturais do indígena, para justificar a ação dos missionários.

$\mathrm{E}$, dentro da historiografia missioneira, muitas são as obras e as declarações dos jesuítas que servem de base e de fonte de consulta para a reconstruçấo do passado histórico ter claro as intençōes subjetivas que se colocam por detrás destas declarações, sob - risco de, em se fundamentando nelas, recriar o passado com os mesmos vícios analíticos destes primeiros historiadores. $\mathrm{O}$ fato de 
Teschauer menosprezar as instituiçöes tribais e o tipo de liderança que possuíam, indicam a dificuldade do autor de reunir e transcrever os diversos aspectos que se encerram no processo de transformação pelo qual passaram as aldeias guarani. De um estágio do "neolítico tropical" os guarani passam a se integrar, através dos Povoados Missioneiros, na Idade Moderna, num processo de interaçâo social e cultural extremamente complexo. ${ }^{17}$ Neste processo mudam os padróes de subsistência, a organização política e o universo mental das tradições e costumes das populações indígenas agora reduzidas.

Quanto à segunda acusação, "o systema adoptado pelos Missionarios promovia o communismo sonhado pelos socialistas", 18 o $\mathrm{Au}$ tor chama do "lado social" da mesma questäo analisada anteriormente. Isto é, o aspecto coletivo da construção da personalidade.

"Todos possuiam sua propriedade e que era exatamente este systema que promoviam os Missioneiros e mais a individualidade a personalidade e a dignidade humana de cada um."19

$\mathrm{O}$ argumento maior, utilizado nesta questão, é demonstrar que a tentativa de ver o comunismo, no sistema de Missões, é exatamente pela situação atual (1920) em que se encontram estas ideologias na Europa. A utilização da moderna sociedade industrial como argumento se dá para provar a necessidade que os homens contemporâneos têm de encontrar algum exemplo que tenha "funcionado".com uma ideologia que começa a ganhar espaço na Europa. Entretanto, esta parece ser uma argumentação sem substância histórica, nem comparação factual plausível para a negação. Seu discurso se desenvolve mais para acusar as bases, sob as quais se estrutura a sociedade atual, do que em negar a possibilidade dos missionários do séc. XVII terem efetivado uma teoria surgida somente no séc. XIX e aplicada no princípio do séc. XX.

"Com effeito, reflectindo sobre o estado atual da sociedade particularmente européa, se admira como manifestam tanto zelo pela personalidade dos antigos índios, ao passo que esta mesma se calca aos pés na culta sociedade moderna, fazendo do operário um automato collocando dia e noite em logar inhóspito para fazer as vezes d'uma machina."20 
Sendo assim, o discurso ideológico de Teschauer possui algumas contribuições históricas importantes, mas a necessidade de salvaguardar a ação civilizadora como uma defesa moral, ética e subjetiva, destitui a validade de seus argumentos. Nem mesmo a consideraçáo de que as Reduçöes poderiam representar o espaço possível de vida para as sociedades tribais, ameaçadas pelas frentes de expansão ibérica, nâo tem relevância no texto de Teschauer. Mais do que demonstrar a história factual da formação do RS, Teschauer pretende enaltecer a obra dos missionários. Contando com esta forte carga subjetiva, a obra de Teschauer transforma-se numa ode de louvor à determinação e ao despreendimento destes "santos homens", que se dispuserem a enfrentar uma empresa tão arriscada. Cabe, portanto, ao pesquisador, ao analisar uma obra deste teor, compreender os pressupostos "teóricos" e os objetivos do autor, para conseguir retirar daí contribuiçōes importantes para a reconstrução do passado missioneiro.

\section{II - Jesuítas e índios: intrusos e débeis}

A polêmica da ação da Companhia de Jesus gerou defensores e acusadores, e suas obras passaram a ampliar o panorama da historiografia missioneira. Enquanto o Pe. Teschauer se esforça para enaltecer a obra dos missionários, outros autores elaboram, em termos semelhantes de subjetivismo e enaltecimento, um discurso completamente oposto de condenação às iniciativas dos missionários.

Um exemplo deste tipo de obra é Capitania d'El Rei de autoria do advogado e ensaísta Moysés Vellinho. ${ }^{21} \mathrm{O}$ próprio título indica o que o Autor pretende abordar sobre os "aspectos polêmicos da história da formaçāo do Rio Grande do Sul". O nome de Capitania d'El Rei foi dado ao atual estado, por nunca haver pertencido a donatários, conforme o sistema de colonização empreendido pela coroa portuguesa aos territórios do Brasil. Isto significa que o Autor admite um pressuposto falso, construído, pois considerar o território do Rio Grande do Sul como pertencente à coroa lusitana desde o início da colonização, traduz aquilo que o Autor gostaria que tivesse se dado historicamente. Sem maiores hesitaçōes, o Autor passará o restante do texto tentando provar e justificar seu falso ponto de partida, mesmo sem corresponder ao processo histórico.

Uma tarefa difícil é analisar o texto de Moysés Vellinho sob critérios teórico-metodológicos. Ao se tentar inserir o autor na ten- 
dência positivista, dominante durante muito tempo na historiografia no Rio Grande do Sul, depara-se com uma incrível capacidade do autor de realizar a "exegese histórica". Vellinho não segue em absoluto os princípios de relato e narrativas factuais do Positivismo. Muito antes de apresentar os fatos numa seqüência cronológica, Vellinho seleciona passagens que se aproximam de seu ponto de vista e extrapola nas interpretações, para dar a aparência de argumentação e veracidade às suas afirmações. Não existe, portanto, nem fidelidade às fontes e muito menos à crítica racional e objetiva destas. Numa preocupação de exaltação de heróis construídos (bandeirantes), o Autor ignora os passos básicos de um trabalho com metodologia científica.

"As soluçōes hipotéticas propostas para o problema inicial deverão ser verificadas, mediante a comprovação pelo teste crítico e racional da confrontação com as fontes documentais utilizadas. Uma vez comprovadas, as soluçöes explicativas hipotéticas iniciais se transformam em teorias (...) e se deixássemos de testá-las mediante nossa razão crítica face à nova documentação que continuamente analisamos, estas explicações se transformariam em uma doutrina, deixando de ser ciência." 22

Se inexistem, para o autor, estas preocupações metodológicas para a realização de um trabalho científico, conseqüentemente sua análise demonstra uma história idealizada (e até doutrinária) sobre a formação territorial do Rio Grande do Sul. Esta idealização parte da proposta política e ideológica do autor de construir e exaltar um nacionalismo do Rio Grande do Sul, como inicialmente "brasileiro", e desencadeia uma análise repleta de contradições, apresentando meias-verdades e afirmaçöes subjetivas.

A construção teleológica de Vellinho e a exaltação nacionalista, através dos bandeirantes, vāo esbarrar na ocupação empreendida pelos jesuítas na porção meridional do Brasil. Por isso se manifesta abertamente contra a "intromissão" da coroa espanhola e contra os membros da Companhia de Jesus e seus neófitos, porque "alteraram" a geopolítica da colônia portuguesa. Todavia, sua proposta de defender as iniciativas lusitanas não podem se apartar das contribuições de missionários jesuítas em território brasileiro. A solução deste impasse (defender ou atacar os jesuítas), o Autor 
opta, arbitrariamente, pela mais simples, e, também, a mais contraditória. Divide nacionalmente os jesuítas, considerando então os missionários lusitanos dignos de confiança, enquanto os espanhóis são consderados inimigos. ${ }^{23}$

\section{1 - A CONSTRUÇÃO DA NACIONALIDADE}

Para Vellinho é urgente que se esclaresçam alguns pontos polêmicos e confusos sobre a formação territorial do Rio Grande do Sul. Estes pontos são aqueles que podem deixar em dúvida a quem realmente pertencia os territórios em questão e, principalmente, quem eram os inimigos, nesta configuração geopolítica, das colônias ibéricas. Visando estes objetivos, o autor não poupa ênfase para determinar sua linha de raciocínio.

"É, com efeito, nesses duros entrechoques que o Continente de São Pedro, a antiga Capitania d'El Rei, vai meter as raízes de sua formação. O conflito deflagrado no flanco superior do Rio do Prata, refluiria depois para o solo rio-grandense onde, por fim, iria estender-se a linha de resistência destinada a resguardar as vastas porções meridionais do domínio luso-brasileiro, desde o Paranapanema até as divisas do Rio Grande com o mundo castelhano." 24

O conflito, a que se refere o autor, são as disputas diplomáticas durante os setecentos, nos quais os Sete Povos e a Colônia do Sacramento são os pontos conflitantes. Para o Autor, aí se encontram as raízes da formação do Rio Grande do Sul, e o processo acontecido até então passa para segundo plano. Este pressuposto será, ao longo do texto, aprimorado, de forma a se aproximar cada vez mais da história que o autor gostaria que tivesse acontecido. No texto citado estão claras suas distorções históricas, visando reforçar seu ponto de vista: o desprezo pela configuração geográfica que estava sendo alterada, considerando somente a "futura" área de domínio do Império Português; e a colocação dos portugueses como defensores, "a linha de resistência" do Império Português, ignorando uma das funções das Missōes Jesuítas de estarem exatamente da linha de frente da expansão dos territórios, até então pertencentes à coroa espanhola. 
Os outros argumentos, utilizados pelo autor para reforçar esta exaltação nacionalista, são tão falsos e contraditórios quanto a configuração geográfica. Primeiramente a divisão nacional dos membros da Companhia de Jesus e a distinção de objetivos destes. Em segundo lugar a defesa aberta dos bandeirantes e de seu "instinto de conservação".

Para encadear seu raciocínio de que os jesuítas são os usurpadores do temitório, o Autor vai arbitrariamente redefinir seu posicionamento, colocando os portugueses como fiéis à coroa, interessados somente no caráter evangélico de sua missão e conseqüentemente sem representar nenhum perigo.

“A partir de 1605 até 1637 , os jesuítas portugueses, descendo pela orla marítima, tentaram mais de uma vez estabelecer-se no antigo distrito do Rio Grande (...) com o propósito de reduzir o gentio que aí estanciava - Fatores adversos (...) haveriam de levar a completo desbarato a obra de penetraçāo tentada nestas paragens pelos missionários portuguêses." 25

Já quanto aos missionários espanhós, seus objetivos catequisadores aparecem como a justificativa de propósitos imperialistas e ameaçadores da Companhia de Jesus. Além de estarem categoricamente numa posição de inimigos:

"Nas alturas de 1626 é que os jesuítas espanhóis, depois de destroçados em Guaíra pelos paulistas, (...) se insinuaram na regiāo pela $1^{\circ}$ vez. Vinham em nome de Deus e dos Reis de Castela, parecendo certo que vinham também em nome dos interesses temporais da Companhia de Jesus, que se teria deixado mover por temerários planos de autonomia política. Esses planos haveriam de assumir, na sua expansão ulterior, proporçōes ameaçadoras para a integração geográfica das possessões sul-americanas de Portugal e Espanha, sendo que a de Portugal se achava exposta a riscos mais imediatos em virtude dos crescentes atritos entre bandeirantes e os jesuítas da Província do Paraguai."26

O subjetivismo de afirmações como "parecendo certo" e a arbitrariedade de dividir propósitos entre os missionários da ordem 
dos jesuítas não impedem do autor de considerar seus argumentos fortes e coerentes. $O$ aspecto de autonomia política da Companhia de Jesus e a ameaça que este representa ao Império Lusitano serão abordados no item seguinte. Agora basta demonstrar como o Autor elaborou esta divisāo nacional dos jesuítas, visando classificar a intromissão dos espanhóis em território alheio.

Complementando os desvios realizados até entâo, Vellinho passa a uma elaboração mais ousada - a defesa do bandeirante. Esta, sem dúvida, exigiu do autor toda a habilidade de sua veia literária, para tornar seus argumentos convincentes, ao menos como ficção:

"As provaçōes que os primitivos moradores de São Paulo tiveram que enfrentar e vencer, antes de tomarem pé no Planalto, os tormentos da fome e da intempérie, nâo menos temíveis que a agressividade do gentio, - tudo isso, exacerbando-lhe o instinto de conservação, se havia de conjugar para dispô-los furiosamente à luta pela sobrevivência." 27

Mas, a defesa dos bandeirantes, em contra partida da acusação dos jesuítas, se dá sobretudo porque o Autor equivocadamente quer atribuir a eles o papel de guardiâos do Império Português, justificando então sua empresa capitalista e predatória sobre as populações indígenas.

"Este feito (as incursões paulistas sobre o Tape), aparentemente insulado na crônica do tempo, não deixou de ter sua repercussão em capítulos ulteriores da história destas terras. Se naquele momento os jesuítas do Paraguai não tivessem sido rechaçados, talvez não fosse possível recuperar, mais tarde, a larga região de que eles viriam a apoderar-se a partir de 1687, quando voltaram a insistir no intento de levar suas conquistas político-religiosas até o Atlântico, através da área natural que depois formaria o Rio Grande do Sul. Pois já então, os luso-brasileiros se tinham estabelecido sobre o Rio da Prata, criando assim um argumento poderoso em favor das futuras reivindicações."28

Tendo estas colocações como base, está montado o arcabouço 
do discurso nacionalista, sobre o qual o autor vai buscar explicaçöes e argumentaçōes sobre a ameaça da Companhia de Jesus ao Império Português.

\section{2 - A AMEAÇA DA COMPANHIA DE JESUS}

Uma vez que, na imaginação do Autor, a Ordem Religiosa dos Jesuítas pode ser desdobrada em nacionalidades e objetivos distintos, pouco lhe custa extrapolar as bases do sistema colonial hispano-americano, para ver na ação dos Missionários da Companhia de Jesus uma forte ameaça aos domínios lusitanos. A obra de catequisação para o "Reino de Deus" visava simultaneamente a disputa pela parte que caberia à Companhia no Reino de César". ${ }^{29}$

Para a demonstração destes propósitos, o Autor passa a construir questionamentos sobre a ação da Companhia de Jesus, nestes questionamentos está manifesto seu discurso teleológico.

"Tudo leva a supor que a Companhia de Jesus chegou a alimentar com tenacidade o propósito de construir, no âmago do Novo Mundo, àquele tempo vazio e como que em disponibilidade de um império próprio - o seu império (...)." 30

Algumas páginas antes, com o auxílio de Jaime Cortesão, Moysés Vellinho já definira os limites deste "Império".

"O Império que começara a ser construído nos princípios do séc. XVII, deveria jogar muito longe, suas fronteiras, desceria até o Atlântico a leste e desdobrarse-ia impetuosamente para o Norte, bandeando o coração do Continente através do Brasil, até alcançar o Mar das Antilhas!"31

$\mathrm{Na}$ continuação da citaçāo anterior, o Autor demonstra as possibilidades da Companhia em realizar este "sonho" e de o tornar soberano.

“(...) Encravado entre os domínios nominiais das duas coroas ibéricas, esse Estado singular cresceria sob a égide dos Reis Católicos, mas evoluíria fatalmente para 
a emancipação, já que dispunha, além da jurisdição espiritual, a civil e a criminal, e tinha as mãos livres para organizar-se militarmente." 32

A constante utilização de verbos no futuro e de expressōes condicionais, demonstra o grau de subjetividade das afirmações do autor. Reunindo fatos que existiram com sua "criatividade histórica" (suas elaborações metafísicas sobre o processo histórico), Vellinho encaminha o leitor a acreditar na existência de um plano que desembocaria na criação de um Império Soberano da Ordem Religiosa, dentro dos limites coloniais das coroas ibéricas. Esta extrapolação do autor visa embasar suas conclusōes sobre a ação ameaçadora da Companhia de Jesus, através de seus missionários. No entanto não demonstra, nem sugere como isto se efetivaria. A estória contada por Vellinho fica mais inconsistente, pela absoluta desconsideração ou desconhecimento da complexa teia de relações por instituições do sistema colonial hispano-americano, no qual a Companhia de Jesus é ativa e participante. Um dos objetivos dos Missionários era que seus Povoados se tornassem unidades autônomas economicamente, sem que isto implicasse em soberania política.

"Uma complexa teia de relações políticas inseriram o cacique à estrutura do governo hispano-americano (...) Por outro lado, uma teia de relações religiosas integrava os guranis dos Trinta Povos ao papado ..." 33

Evidentemente que, depois da divisão nacionalista dos jesuítas, esta ameaça era representada somente pelos missionários espanhóis, pois "quanto ao patriotismo dos jesuítas lusitanos, parece fora de dúvidas que os Reis de Portugal sentiam-se tranqüilos". ${ }^{34}$

Para complementar sua visão de que os Sete Povos se constituiam uma ameaça ao Império Lusitano, o Autor vai buscar argumentos na exaltação patriótica do Bandeirante, ocultando e distorcendo os fatos históricos.

"Acima do bem e do mal pelas cruas contingências do meio e da época, a êles, pela sua espantosa mobilidade, pela dureza e desassombro de suas investidas, estava reservada uma fulgurante missão histórica: a integração da América Portuguesa em toda sua exten- 
são (...) O império territorial que herdamos resultou em sua maior parte do bandeirismo. Também nāo ignoramos que uma das barreiras mais resistentes e agressivas que os antigos povoadores tiveram que vencer, para levar adiante sua empresa, foi representada pela ação temporal dos jesuítas." 35

As intençöes de justificativa das empresas bandeirantes chega às raias da idolatria, pois acima da verdade está o sentimento patriótico que guiava aqueles "corajosos homens", tanto quanto direcionava o pensamento do Autor ao escrever essas passagens. Nestas, as empresas predatórias e capitalistas são sinônimos de "integração". Sua postura ideológica é tão clara e evidente em defesa do nacionalismo, que, sem muitas explicações, reúne num mesmo campo (inimigo) todos os jesuítas, abolindo a distinção que havia efetuado anteriormente. Mais do que isso, os jesuítas passam a representar a negação desta integração, são os sujeịtos da resistência e não da contra-ofensiva aos bandeirantes. $\mathrm{Na}$ continuidade da defesa destes últimos, o Autor passará a realizar extrapolações ainda maiores

“De marcos de pura evangelização que deviam ser, as reduções se converteriam logo em verdadeiros núcleos de preparação militar, sempre a serviço das necessidades agressivas ou defensivas de Buenos Aires." 36

A princípio desconsidera totalmente o aspecto institucional das Missões e a abrangência que implicava a formação de Reduções através do binômio catequisar/civilizar. A civilização ultrapassa os limites de "pura evangelização". A seguir, a autorização do monarca espanhol para que cada Povoado possuísse o seu depósito de armas, só veio com a Cédula Real de 1679. Durante mais de cinqüenta anos, os missionários defendiam esta idéia em função das contínuas devastaçōes provocadas pelos bandeirantes. Portanto nảo foi tão rápido como sugere o Autor.|As Missōes, enquanto instituiçōs de fronteira, de linha de frente da expansão e colonização da coroa espanhola, necessitavam efetivamente de exércitos e armamentos. Todavia, o preparo militar era rigidamente controlado pelos missionários e sustentados pela coroa, para the prestar serviços. E, ao se considerar as Míssōes a serviço das necessidades estratégicas de defesa ou ataque, nảo se pode desvincular a preparação militar. Por último, conforme as posiçöes anteriores do Autor, parece que 
neste momento, os jesuítas abandonaram o seu plano de construção de um Império, transformando repentinamente as Missões em núcleos militares de defesa dos interesses do Rei da Espanha. Na seqüência de seu discuso, oAutor chegará à apologia do exagero, transformando a Província Jesuítica do Paraguai numa "temível potência militar", talvez a "maior da América do Sul".37

Esta manipulação de dados e as constantes distorções dos fatos demonstram o "esforço" do Autor para contar a história que gostaria que tivesse acontecido.

Um último elemento considerado por Vellinho, de forma equivocada, para transformar a ação da Companhia de Jesus em ameaça ao Império Português, será a própria configuração do sistema missioneiro que se desdobra em vários aspectos, Entre estes aspectos, está o que mais interessa ao presente estudo, ou seja, as caracterizaçöes do indígena e do jesuíta. O estabelecimento dos Sete Povos se configura como uma empresa ameaçadora por seus propósitos políticos e, ao mesmo tempo, fadada ao fracasso por sua composição social e étnica.

\section{3 - ORGANIZAÇÃO FADADA AO FRACASSO}

Até o presente momento, buscou-se delinear como o Autor constrói seu discuso, os recursos que utiliza e os vícios metodológicos que possui sua análise. Para a comprovação de sua tese da negação sobre a formação territorial do Rio Grande do Sul, o Autor, ao longo do texto, vai elaborando sujeitos e acrescentando sobre eles um conjunto de variáveis do processo analisado. Assim ele procedeu com os princípios políticos e os problemas de fronteira das coroas ibéricas; com os objetivos da Companhia de Jesus e com os bandeirantes. Ao utilizar este recurso, desvirtuou em muitas vezes a noção de processo histórico e, freqüentemente, integrou aos sujeitos em questão variáveis que sua posição e seu papel social no contexto não comportavam. Agora, com a intenção de mostrar que o sistema missioneiro é, em suas raízes, fadado ao fracasso, - Autor será coerente com sua "arbitrária criação metodológica". A contradição do Autor se verificará sobre a definição do sistema missioneiro, que ora é um "inevitável fracasso", e ora se traduz como "portentosa experiência". O fracasso será atribuído ao indígena; enquanto que a ambiciosa liđerança jesuítica será responsável pela impossibilidade da continuação da experiência. Todas essas 
posiçôes contraditórias pretendem embasar e argumentar a conclusão final do Autor - a inutilidade do legado cultural das Missōes estabelecidas no atual território do Rio Grande do Sul.

Ao se referir ao sujeito-índio, o Autor elabora um discurso por vezes romântico, mas freqüentemente etnocentrista, o discriminatório e com profundas contradiçōes. As contradiçōes do Autor, sobre o índio, percorrem uma parábola que inicia com um extremo desconhecimento das sociedades tribais, passa pelo máximo do preconceito e termina na mais completa manipulação e distorção dos dados.

Primeiramente qualifica o índio como um idiota, subhumano e tẫo atrasado culturalmente que o regime de escravidão se impõe como uma "lei de vida".

"Preando os índios e escravizando-os - aqueles bárbaros que viviam em guerras permanentes e devorando-se uns aos outros - os colonos se limitaram a cumprir uma lei da vida." 38

Mas, segundo o Autor, não são somente os colonos que escravisam os indígenas. A "lei da vida" é aplicada também pelos jesuítas. Apresentando exemplos de como os jesuítas se utilizavam do trabalho escravo (a maioria não se refere a escravo indígena) e mostrando que os missionários montavam expedições, que "tinham como remate natural o aprisionamento e a escravização dos (índios) rebeldes", 29 Moysés Vellinho ignora um dos princípios da política da Companhia de Jesus em relação ao índio. Isto é, livrar o índio, que se convertesse ao cristianismo e que passasse a viver no Povoado, do regime de mita e encomienda.

Num segundo momento, pretendendo demonstrar a ameaça que as Missōes representam, utiliza-se da "eficiência de homens e armas", do "aguerrido exército guarani", 40 que, evidentemente, é formado por aqueles indígenas caracterizados como semi-bárbaros, débeis e idiotas.

Sendo assim, conforme o autor, pode-se apontar duas razões que contribuiram para o fracasso das Missöes: os objetivos temporais dos jesuítas que acabaram por desviar os princípios e os propósitos das Missőes;

"Incomparáveis mestres de trabalho, duros, vigilantes, 
os jesuítas insensívelmente foram deixando que os objetivos espirituais pregados por Loyola cedessem em favor dos temerários planos temporais da Companhia. Chegou o ponto em que já não se sabia ao certo se se tratava de um empreendimento religioso ou mais propriamente de uma vasta organização econômica, alimentada por vultuosas operaçōes mercantis inteiramente isentas de direitos" 41

e a baixa qualidade do material humano trabalhado por estes missionários.

"A verdade é que a grande experiência sob tantos aspectos portentosa padeceu de males que comprometiam desde o fundo a própria viabilidade do sonho jesuítico (...) Além de tudo, o material humano ali experimentado, do mais baixo teor, era quase inaproveitável, senão inaproveitável de todo, como fator de civilização." 42

E mais adiante complementa que

"Dificilmente se poderia, com efeito construir qualquer coisa de estável e duradouro sobre o casco indígena, pobre gente que talvez nem se pudesse considerar como padrão de raça primitiva, mas já em estado de franca regressão." 43

As passagens, citadas acima, servem para mostrar o quanto sẩo contraditórias as visões doAutor sobre os dois sujeitos e quanto o discurso e as definições sobre o sistema missioneiro mudam, conforme se refere ao jesuíta ou ao índio.

Sob a liderança dos padres, as Missōes se constituem numa "vasta organização econômica, alimentada por vultuosas operações mercantis", uma empresa que se desvirtuava de seus propósitos religiosos, para se tornar ponta de lança de um audacioso projeto temporal da Companhia de Jesus. Projeto aliás que já tinha sido abandonado, e que agora é novamente retomado. Todavia, esta vasta organização econômica se torna inviável, porque se constitui fundamentalmente por índios. A seguir, já não existe nada de estável e duradouro, "porque os indivíduos que a compõem são seres em 
'franca regressão' ". Toas estas qualificaçōes se referem à organização do sistema dos Trinta Povos, aparentemente durante um mesmo período histórico. As distorçöes factuais e discursivas são evidentes, pois nảo é necessário um profundo conhecimento histórico, para perceber que um mesmo objeto não pode ser tão mutável numa dada circunstância.

O sistema econômico das Missōes não comportava as "vultosas operaçöes mercantis", pois a economia visava fundamentalmente a autonomia dos Povoados. As exportaçōes de erva-mate se realizavam através de uma barca anual, visando abastecer os Povoados de produtos não manufaturáveis no local. "A produção missioneira continuou sempre voltada para o consumo, sem visar mercados (...) mantinha-se assim a característica de autarquia econômica e de solidarismo interno". ${ }^{44}$

Entretanto, se a constituição deste sistema econômico está baseado na produção dos indígenas, como teria se transformado em algo tão importante, como assinala Vellinho, se os indígenas não possuíam condições mínimas para serem civilizados? Isto sem contar que civilizar, para os jesuítas, implicava em "reduzir à vida política e humana", ou seja, tomar o índio apto a sustentar um sistema econômico, que não precisava ser vasto e complexo; bastando que se aproximasse dos padrões europeus de produção. Todavia, os mesmos jesuítas, que moldaram as sociedades tribais e as colocaram dentro destes padrões sócio-econômicos e políticos da Idade Moderna, não realizaram ao longo de 150 anos nada de duradouranem estável. Estariam durante um século e meio "preparando" as bases de seu Império Teocrático?

Assim como estes exemplos, existem outros conforme o aspecto abordado pelo autor. O sistema missioneiro construído pelos missionários com os indígenas atinge os estremos de portentoso e débil. A sociedade passa de escravocrata para coletivista e de segregativa para o mais profundo sentimento de auto-destruição dos indígenas. Os índios passam por elementos especializados, hábeis e treinados até a inapetência global para qualquer atividade. Os princípios culturais e tradicionais dos guarani são vistos como teimosia, aversão ao trabalho e inclinação para os vícios; sobre os quais se tornam inúteis todo e qualquer tipo de trabalho dos missionários. Todas estas contradições aparecem ao longo do texto de Moysés Vellinho e adquirem sentido, somente quando o Autor esclarece que: 
"Dos campos de trabalho e exercícios de guerra que, ao lado do esplendor e das festas litúrgicas, emprestaram, um dia, vida e calor à clausura missioneira, nenhum legado cultural digno de ser levado em conta (...) Só uma coisa nos ficou do passado morto: o papel depositário de ruínas alheias (...) O certo é que a vida pregressa das missōes jesuíticas, estranha e hostil à formação rio-grandense, já estava inteiramente desmantelada, sociologicamente inerte, quando a antiga área missioneira foi anexada ao domínio luso-brasileiro." 45

Pelos textos acima, fica claro o sentido e a coerência que Moysés Vellinho quis dar às suas contraditórias afirmaçōes. Elas visam, sobretudo, convencer um leitor desatento, que a história do Rio Grande do Sul teve uma dinâmica própria, quase que desconectada do restante do mundo hispano-americano. Sua pouca habilidade em manusear os dados e sua incrível capacidade literária unemse numa tentativa de distorcer o processo histórico, integrando o Rio Grande do Sul ao Império lusitano, quando a área era ainda pertencente aos domínios espanhóis.

III - Jesuíta e índio: alicerces do socialismo missioneiro

\section{1 - CONSIDERAÇÕES INICIAIS}

"Existe ainda um território do historiador?" A indagação foi feita por Le Goff e Pierre Nora na apresentaçāo do volume História: novos problemas. Aqui é repetida de uma forma mais agastada do que questionadora. Talvez por falhas ou omissōes dos historiadores, ou por aventurismo de outros estudiosos, a verdade é que o campo da História é bastante permeável, e tem sido constantemente invadido e apropriado por políticos, ideólogos, sociólogos que se sentem capazes de manipular as categorias de análises da História. Neste sentido, cabe o quadro traçado por Pierre Vilar.

"O comércio da história possui alguma coisa em comum com o comércio de detergentes, onde facilmente tomase a novidade por inovação. Existe, porém, uma diferença; as marcas na história encontram-se desprote- 
gidas. Qualquer pessoa pode dizer-se historiador. Qualquer pessoa pode acrescentar 'marxista'. Qualquer pessoa pode qualificar qualquer coisa de 'marxista'."46

Certas produções, enquadradas na historiografia, parecem comprovar que, entre as Ciências Sociais, a História parece realmente ser este campo de ninguém. Basta ter uma boa veia literária, uma idéia inovadora, acrescentar um modelo teórico "de peso" a realizar uma leitura superficial sobre o assunto: após uma rápida elaboraçăo, estará pronta uma obra fantástica e impressionante, talvez, até um best-seller de vendagem; mas que fica muito a dever para uma produção histórica. Se a intromissão de "alheios" no campo da História resulta das omissōes dos próprios historiadores, é certamente porque possuem a dimensão de todo o trabalho de pesquisa e elaboração, que deve existir, antes de tornar público suas investigações.

Estes cuidados nāo foram tomadas pelo advogado e professor Décio Freitas, ao publicar em 1982 O Socialismo Missioneiro. Nesta sintética obra, o Autor demonstra sua habilidade para construções teóricas fictícias, através de uma leitura apressada de algumas fontes documentais. Para Freitas, o caso Missōes constitui-se como uma especificidade dentro do processo colonial "brasileiro". Sua proposta teórico-metodológica é primeiro enquadrar a experiência missioneira nas categorias de análise do materialismo histórico; para, num segundo momento, resgatar esta experiência para a memória social das atuais lutas pelo socialismo na América Latina.

Sem dúvida, o caso Décio Freitas/Missões é um exemplo da permeabilidade do campo da História e de invasão do território do historiador. Assumindo o papel de historiador, Décio Freitas se apropria da História para elaborar a sua visão político-social do mundo atual. Mas, nesta sua aventura, despreza não só as categorias de análise da História, como simplifica, de forma empobrecedora, as do materialismo histórico. O resultado é uma interpretação equivocada do processo histórico, desconectada com as fontes documentais e com o próprio modelo teórico utilizado.

“ 'Uma verdadeira' história marxista para se contruir deve (...) ir sem cessar de uma pesquisa ao mesmo tempo paciente e ampla a uma teoria que nảo recua, diante de qualquer rigor, mas também ir da 'teoria' ao 'caso' afim de não permanecer como'saber inctil." 47 
Para encontrar, na experiência missioneira, os princípios de uma sociedade socialista, o Autor utilizou-se por vezes de argumentos subjetivos, de lugares-comuns, apresentou como verdadeiros dados hipotéticos e, sobretudo, manipulou, distorceu e omitiu fatos históricos. Assim, a nível teórico-metodológico, Freitas se aproxima das mesmas arbitrariedades cometidas por Moysés Vellinho; com - agravante de praticamente ignorar os esforços e os progressos conseguidos pelas ciências no tempo que o separam.

Todavia, é inegável que a obra de Décio Freitas constitui-se num grande exercício de abstração e de construção metafísica. Pois, ver, na estrutura e nas relações sociais dominadas pela ideologia do catolicismo contra-reformista e pelo absolutismo monárquico do séc. XVII, a "praxis" de teorias elaboradas durante o século XIX e que passaram à aplicabilidade somente no século $X X$, requer um grande esforço de extrapolação. São propósitos como esses que emprestam à obra de Décio Freitas um caráter mais idealista do que materialista, como certamente é seu objetivo.

Muitas das arbitrariedades e contradiçōes, do discurso de Décio Freitas, resultam de sua estreita visão sobre a complexidade do processo histórico em questão. Neste aspecto em particular, as limitaçōes de Décio Freitas o encaminham para uma interpretação falha e unilateral.

“Desde tempos remotos havia homens neste território, mas sua existência anterior a 1626 é desconhecida, ou seja, pertence ao obscuro domínio da pré-história. Não dispomos senão de algumas indicações, mais ou menos vagas, da etnografia e da lingüística, fontes de restrito valor para a história." 48

O desprezo do Autor para com áreas afins com a História é gritante. Ultimamente, a ciência histórica tem procurado ampliar cada vez mais seu campo de investigação, visando elaborar uma análise mais abrangente. A consideração de inúmeras variáveis, que atuam numa determinada circunstância, bem como a busca de contribuições de ciências fronteiriças dạ História demonstram que essa ampliação é enriquecedora para as interpretações. O caso das Missões é um exemplo claro de quanto é necessário que a abordagem sobre um aspecto seja de forma inter-disciplinar. 
leve em conta os conhecimentos e teorias da antropologia, da Etno-história, da Arqueologia e da História, entre outras, poderá tentar com algum sucesso a reconstrução deste processo histórico tão complexo". ${ }^{49}$

Sendo assim, na análise realizada sobre a obra de Décio Freitas, procura se salientar as manipulaçōes discursivas elaboradas sobre o elemento indígena e sobre o jesuíta. $\mathrm{Na}$ sua construção sobre o socialismo missioneiro será analisado basicamente as características da sociedade igualitária delineada pelo Autor.

\section{2 - ÍNDIOS E SISTEMA MISSIONEIRO}

Ao tratar da população missioneira que compunha o sistema missioneiro, percebe-se o quanto o Autorleva a sério a sua desconsideração às ciências fronteiriças da História. Sua análise sobre os guarani é anacrônica com os progressos da Antropologia e da Etnohistória. As conclusões a que chega, sobre a relação entre os guarani e o sistema missioneiro, primam pela simplificação de suposiçōes e são próprias de quem não se deteve na parte fundamental da elaboração, ou seja, a pesquisa. Como sua consulta às fontes ${ }^{50}$ não pressupõe nenhuma crítica interna ou externa, a visão apresentada sobre os guarani assemelha-se àquelas produzidas pelos primeiros missionários do século XVI e XVII. Utilizando-se da descrição de um jesuíta, o Pe. Romero, procura embasar sua opiniảo de que nâo se deve idealizar as condiçōes de existência dos guarani antes da conquista. Ao apresentar tal descriçāo, subtende-se que esta seja sua visão sobre as sociedades tribais.

"Não há ano algum em que esses pobrezin̨hos naturais nâo padeçam de mil calamidades e desventuras de fomes, frio, enfermidades e mortandades de que abundam todas essas terras, causadas sem dúvida de pouco governo e previsâo que têm em cuidar de suas terras (...). Nem menos ainda têm tratamento algum com que possam amenizar seus trabalhos e suas dores." 51

Manifesta-se neste texto o desconhecimento do modo de vida das sociedades tribais. Tal desconhecimento poderia ser compreensível ao ser expressado por um missionário do séc. XVI, que escrevia 
com a mentalidade carregada de princípios europeus, escandalizando-se com a aparência miserável da vida dos grupos indígenas.

Todavia, a qualificação da economia tribal, como insuficiente, está ligada mais a preconceitos e às tentativas de justificar o modo de produção da sociedade moderna.

"Ao contrário de nossa economia, os grupos indígenas produzem para viver, mas nāo vivem para produzir. Ao lado de uma divisão sexual do trabalho, a produção é segmentária, apenas para o consumo e o acesso aos meios de produção é autônomo." 52

Além do equívoco quanto ao aspecto econômico, existe na continuidade da descrição um segundo erro, no que se refere ao modo de vida e aos problemas sociais enfrentados por estas sociedades. Quanto a estes últimos aspectos, denota-se um completo desconhecimento da cosmovisão dos grupos indígenas, os tipos e papéis sociais desempenhados pelos diversos membros do grupo.

Um exemplo referenciado no texto é o descaso da figura do xamã e suas funções, entre elas a cura de doenças. Pela descrição, inexistem todos os rituais de responsabilidade do xamã para a descoberta da causa da doença e os que se seguem para providenciar a cura desta. Este indivíduo só será visto, mais adiante, como representante da ideologia guarani, se opondo a qualquer mudança na estrutura econômica. ${ }^{53} \mathrm{~A}$ desconsideração do xamã pelo jesuíta autor da descrição é compreensível, pois eram fortes opositores. O que não se justifica é considerar o xamã somente se opondo a mudanças na estrutura econômica, pois na sociedade tribal, não se divide institucionalmente economia, política e religiāo. A oposiçăo do xamã é contra qualquer princípio colonizador.

Decorrente à descrição do Pe. Romero, Décio Freitas conclui que o nível de vida dos guarani é "baixíssimo". Sua análise fica grosseira quando se refere à mortalidade infantil, como causa determinante da baixa expectativa de vida, desvinculando a relação entre produção/população; e ainda mais quando liga a tradição antropofágica à fome. Para completar esta distorção sobre a organização social guarani, se refere à diferenciação social existente entre os caciques e o restante do grupo.

"Os caciques gozavam de certos direitos sobre seus súditos, que deviam semear e cultivar as terras, bem 
como entregar-lhes os filhos quando solicitassem. A poligamia estava reservada aos caciques, dado que o grosso dos homens da tribo não podia manter várias esposas (...) Sociedades sem classes, não conheciam qualquer tipo de vida política." 54

Primeiramente, que entre as sociedades tribais não existia essa figura com um poder tirânico. O chefe de linhagem era detentor de tradiçōes cotidianas da tribo, assumindo liderança frente ao grupo somente em situações limites como guerras ou desavenças internas. Ainda assim, no caso de guerra era comum escolherem um guerreiro forte e capaz de liderar o grupo.

O seguimento da citação pode ser traduzido como uma profunda confusão, pois trata de economia - "entrega de filhos"(?) e sobre poligamia, formando uma verdadeira "colcha de retalhos", onde aparecem vários aspectos sem uma explicação conveniente. No que se refere aos "súditos ter o dever de semear e cultivar as terras", parece existir a completa ignorância da propriedade cacical típica desta sociedade. Ao cacique cabe a distribuição das terras às famílias e a administração sobre estas últimas. O núcleo familiar é responsável pela produção, possuido a terra e os meios de produção." 55

Em relação à poligamia, a confusão se torna ainda maior. Realmente, a poligamia era exclusiva dos caciques. Entretanto, a exclusividade nảo se relaciona com o fato do restante dos homenš não poderem sustentar várias esposas. Era o desempenho das funções cacicais que dava direito à poligamia, direito aliás que se constituía quase num dever, pois era através de suas esposas que o chefe mantinha sua generosidade e reciprocidade para com o grupo.

Portanto, nảo era o chefe que mantinha suas esposas, mas sim as suas mulheres que o ajudavam a se manter na posição de chefia. Os caciques recebiam presentes de toda a tribo, e devia devolver-lhes em maior quantidade. Seria impossível manter essas relaçōes se não fosse pelas produçōes de suas mulheres. A poligamia era, então, uma instituição fundamental para a existência do grupo como tal, através da manutenção das relaçōes do binômio reciprocidade/redistribuição.

A insistência das colocaçōes de ordem econômica, sobre a "crise dos grupos guarani", visam embasar a conclusảo de que "os índios queriam de fato ser reduzidos". ${ }^{56}$ Levando-se em conside- 
ração as pressōes da colonização espanhola (mita e encomienda) e das frentes expansionistas lusitanas (os bandeirantes), que implicam num genocídio disfarçado; realmente os grupos guarani poderiam ter considerado a alternativa da sobrevivência física dentro das reduçōes. Mas, daí a afirmar que o índio optaria deliberadamente pelo abandono de sua cultura e sua tradição tribal e aceitaria a transformaçāo, que implica o "catequismo e civilizar", se torna uma grande abstração e um abandono de todos os conhecimentos antropológicos.

Desta forma, as consideraçöes antropológicas do Autor não merecem sequer a qualificação de construção teórica, pois para isto necessitaria um mínimo de dados que inexistem em sua análise.

\section{3 - COMPANHIA DE JESUS, JESUÍTAS E SISTEMA MISSIONEIRO}

Para seguir os objetivos deste estudo, se pretende retirar das construçōes de Décio Freitas o papel da Companhia de Jesus e os propósitos e funçỏes dos missionários no sistema missioneiro. Entretanto, a tarefa se dificulta, na medida em que o Autor se contradiz seguidamente num discurso teleológico, onde quase não existe o desenvolvimento das idéias.

Para desenvolver o capítulo "Jesuítas e Missões", o Autor inicia com um questionamento que lhe servirá mais como premissa do que como guia de investigação.

“...se o evangelismo e o humanitarismo não representam a máscara ideológica de um projeto social. A indagação é tanto mais pertinente quanto mais as mentalidades pré-capitalistas eram incapazes de articular um discurso declaramente social e político, recorrendo ao discurso religioso para fundamentar o projeto social." 57

É perceptível, pela construção teleológica, que a análise não discorre sobre a possibilidade de negação da existência deste "projeto social"'. Pelo contrário, o discurso de Décio Freitas busca sobretudo confirmar a aplicação pelos jesuítas deste "projeto social"; embora não consiga escapar das contradições inerentes a tal afirmaçāo. 
Sobre a característica básica da Companhia de Jesus "um aparelho, de resistência sistemática contra o protestantismo e como órgão fiel do Papado", ${ }^{28}$ o Autor vai atribuindo diferentes papéis à Companhia e seus membros. Num primeiro momento, enquanto na Europa a Ordem Religiosa "desempenhará um papel reacionário (...) na América, os jesuítas se integrarāo na ordem colonial". 59 Para confirmar a integração dos jesuítas ao sistema colonial, o Autor utiliza-se das atitudes dos primeiros jesuítas; que parecem agir por conta própria, pois não se menciona a ligação entre instituição/missionários "possuem enormes latifúndios, exploram o trabalho de escravos, se valem da mita, acumulam grandes riquezas e praticam contrabando". ${ }^{60}$ Seriam estes os princípios de aplicação do "projeto social", ou o humanitarismo inexistiu neste primeiro período? A princípio, parece que, para o Autor, humanitarismo/escravidão são palavras que não possuem nenhuma relação, pois os jesuítas continuam possuido escravos e continuam sendo os propulsores do projeto social.

As distinções de papel, conforme o local em que se encontram, e a aparência de uma certa autonomia dos missionários, em relação à hierarquia da Ordem, manifestam a inaptidão do Autor para tratar do complexo histórico que encerra o sistema colonial hispano-americano. Sem maiores comentários sobre as falhas do vocabulário histórico, cometidas ao associar a Companhia de Jesus a "aparelho" e depois a "reacionário"; o objetivo maior da Companhia era a difusão do catolicismo. Nesta empresa, teve que adotar uma forma de açäo para reconquistar a Europa dividida pelo protestantismo. Frente ao espaço vazio e à população atéia no Novo Mundo, teria necessariamente que agir diferente em função de uma nova circunstância. Através da Companhia de Jesus, e da ligação desta com as monarquias católicas européias, os jesuítas se integram no sistema colonial, para realizar a "Conquista espiritual" e resguardar os domínios das coroas. Embora isto não sirva de justificativa para defender ou acusar a ação dos jesuítas, há de se compreender que não era a Companhia de Jesus e seus membros que mudavam, mas sim as circunstâncias, nas quais atuavam, lhe exigiam diferentes atitudes.

O mesmo equívoco acontece em relação aos missionários. Quando oAutor'se refere aos jesuítas responsáveis pelas Reduçōes", a Companhia de Jesus já comporta uma coisa só tanto na Europa, quanto na Américá, mudando o que os missionários desempenham a frente dos Povoados. "Os jesuítas seräo uma coisa na Europa e na colônia, e outra muito diferente nas 'reduçöes' ". ${ }^{61}$ Numa ordem 
como a dos jesuítas, fundada sobre os princípios de disciplina e obediência, é difícil imaginar que "coisa muito diferente" seria um missionário responsável por uma Redução. Que tipo de autonomia teria esse jesuíta, pois na colônia não estava integrado ao sistema colonial? Ou será que integração significaria intenção e desenvolvimento de um "projeto social" individualizado, pois não estaria vinculado nem à instituição religiosa, nem à coroa. Em realidade, pode se dizer até que existe um padrão de comportamento, papéis e funçôes a serem cumpridas por um jesuíta designado para fundar e orientar um Povoado.

Os exemplos citados, até o momento, servem para indicar que inexiste no discurso de Décio Freitas uma linha metodológica e mais do que isso, não aparece nem a preocupação com uma certa precisão terminológica para dar aparência de um texto coerente. Assim ele continua a proceder quando se refere aos objetivos dos jesuítas. Ao descrever estes personagens e delinear atitudes, torna-se claro que a proposta do Autoré enquadrar os padres (e quase independente da Ordem a que pertenciam) como responsáveis pela construção do Socialismo Missioneiro.

"Nas reduções guaranis, os jesuítas organizaram uma sociedade igualitária que faz pensar nas concepções comunistas cristãs (...) os padres não tiveram nas missões guaranis outros interesses que o religioso e o humanitários (...) Numa réplica a um colonialismo fundado no latifúndio e na escravidão, criaram comunidades livres, fratemais, igualitárias, sem usar outras armas que a compreensão e a persuasão em contraste com a maciça e inumana violência que marcou o empreendimento colonial". 62

O esforço do Autor, para demonstrar a existência do "projeto social" dos missionários, percorre um longo e inútil caminho. Inicia com a aproximação das idéias da Igreja com o comunismo dos primeiros cristãos, passa por "heresias revolucionárias" da Idade Média e vai desembocar no revigorar das idéias comunistas, através das obras de Thomas Morus e Campanella. Todas estas análises sāo extremamente aleatórias e superficiais e servem para apontar uma "hipótese plausível, mas sem qualquer prova", que os missionários do Paraguai teriam aplicado os princípios coletivistas e igualitários, que constam em a Utopia e na Cidade do Sol dos Autores 
supra-citados. ${ }^{63} \mathrm{~A}$ História, enquanto ciência, não se vale de aceitar, como certas, "hipóteses plausíveis", pois é exatamente no esforço em apresentar dados concretos e comprovados, que reside sua proposta de se constituir como área de produção de conhecimento. A falha grosseira de Décio Freitas está não somente na utilização da abstração, mas principalmente no desconhecimento das categorias e princípios analíticos da História.

Outro aspecto relevante, a ser comentado, é o fato do autor, num primeiro momento, associar o igualitarismo e o coletivismo existente nas Missões como obra e responsabilidade dos jesuítas ("os jesuítas organizaram uma sociedade igualitária"). Logo depois, como sua hipótese era somente plausível, se referencia ao "coletivismo das reduções traduziu uma exigência das massas guaranis. Elas é que conquistaram os padres, não os padres a elas". ${ }^{64}$ Além da contradição, o radicalismo das duas afirmações as afasta daquilo que as fontes etnográficas e históricas indicam como realidade. A manutenção dos princípios comunitários e coletivistas dos guarani se deu em troca do abandono de outros valores e tradições tribais, como por exemplo a poligamia. Portanto, a noção de comunidade coletivista dos Povoados é fruto de um pacto social realizado entre os padrões da sociedade européia com os da sociedade guarani.

O cunho coletivista dos Povoados será utilizado, pelo autor, para fundamentar as bases econômicas do Socialismo Missioneiro. O dirigismo ideológico de Décio Freitas extrapola os limites da História e passa a distorcer os fatos, na tentativa de demonstrara possibilidade de existência deste sistema nas Misōes. A partir da definição elaborada pelo Autor, ele busca reconhecer as bases do socialismo nas questões da propriedade e dos bens.

"O sistema socialista se define ainda como aquele em que são comuns não apenas a propriedade e gestão dos meios de produção: terras, ferramentas de trabalho, minas, fábricas, bancos, etc. - mas também a apropriação e distribuição do produto social." 65

Como já foi colocado, o coletivismo que existe nas missões se deve a integração no Povoado das sociedades européia e indígena. Mas, não somente $a$ isto, como também às determinações da própria coroa espanhola. As Cédulas Reais, de 1565 e 1598 de Felipe II, já estabeleciam a existência do Tupambaé, ou seja, "una masa de bienes comunes" ao lado dos bens particulares. ${ }^{66}$ Entretanto, nảo 
se pode afirmar que a propriedade comum seja superior à propriedade familiar, a ponto de caracterizar todo o sistema econômico das Reduções. Primeiro, porque o regime de trabalho, no Tupambaé, consta de apenas dois dias por semana. Em segundo lugar, porque sua produção se destina a atender às necessidades do Cura, das mulheres do Cotiguaçu, aos doentes ou àquelas que porventura tivessem fracasso em suas plantaçōes/provisōes, necessitando assim de uma ajuda de emergência. Assim, embora a produção da propriedade comum sirva a todos (que necessitarem) sua distribuião não é igualitária.

Evidentemente, que o sistema econômico e a questão da propriedade são bem mais complexas do que foi apresentado aqui; entretanto, não é objetivo do presente estudo aprofundar este aspecto, mas sim a questão do social que está implícita nesta "sociedade socialista". A princípio sob o título "Formação Social Missioneira", ${ }^{67}$ o Autor descreve a organização do sistema econômico. Divide as Reduçōes em zonas rurais e urbanas, e abstrai uma pseudoharmonia existente nesta sociedade. A máscara de perfeito consenso, traçada por Décio Freitas, serve muito mais a seus propósitos ideológicos, do que a uma tentativa de reconstrução da sociedade jesuítico-guarani.

Décio Freitas busca na sociedade missioneira um exemplo de comunidade igualitária, afastando-se do propósito de reconstrução histórica e da correlação racional e objetiva entre passado/presente. Numa elaboração panfletária com fins ideológicos bem definidos em relação a atual situação política da América do Sul, o Autor demonstra mais preocupações de político e sociólogo do que de historiador.

Através dos princípios que regem o sistema socialista e da inserção destes na organização social missioneira, se percebe os desvios e manipulaçōes do Autor, para demonstrar a existência deste sistema nas missões.

"Na sua essência, o socialismo concebe uma sociedade sem classes - uma sociedade sem explorados, possuidores e despossuídos, opressores e oprimidos. O sistema terá como base a propriedade social dos meios de produção, ao invés da propriedade privada, como sucede no capitalismo e antes sucedera em outras sociedades." 68 
Em realidade a sociedade missioneira não comporta classes sociais como as existentes num sistema capitalista moderno mas, isto não significa necessariamente que seja uma sociedade igualitária. Apelar para o determinismo e tentar definir uma sociedade por aquilo que ela nāo possui é uma forçosa manipulação de discurso e uma abstração, que não esclarece em nada o problema. Conforme os grupos em presença no Povoado (jesuítas, caciques, cabildantes, artífices, etc.), passa a existir uma série de funções especializadas, que não existiam na sociedade tribal. Essas especializações vão influir não só na hierarquia de poderes, mas também na distribuição espacial destes grupos no Povoado.

A conjunção das contradições e superficialidades de Décio Freitas, apresentadas até o momento, visam sobretudo indicar que a análise de um complexo processo histórico, no qual as Missões estão inseridas, está sujeito a se deformar e apresentar-se simplório e determinista. É necessário contar com modelos teóricos, metodológicos de pesquisa e especialistas que partam dos problemas colocados pela própria realidade histórica analisada, e não transformem esta realidade em propostas de solução para problemas atuais.

"Seria mais urgente elaborar os métodos para passar
da teoria à análise 'de casos', onde geralmente não
se trata nem de um único modo de produção, nem
de uma 'transição' sem direção a um deles, mas de
uma comtinação complexa, por vezes bastante comple-
xa, por vezes bastante estável, não somente de 'dois',
mas de 'vários' modos de produção." 69

Se existisse uma "lei" aplicável a todas as ciências (exatas e humanas), nesta deveria constar que "não se deve manipular com elementos que não se conhece", pois assim se evitaria perigos desastrosos, quer físicos, quer analíticos, como os exemplos aqui demonstrados.

\section{Conclusōes}

O presente estudo consta de uma análise crítica sobre três obras e seus respectivos Autores, que contribuem distintamente para a historiografia missioneira. Nesta análise, buscou-se salientar os 
aspectos da estrutura e organizaçăo social dos Povoados Missioneiros. O privilégio, dado à questão social, se desdobrou na análise das posiçōes dos Autores sobre a participação dos elementos indígena e jesuíta e sobre o papel desempenhado pela Companhia de Jesus no processo de colonização e instalação das Missóes. Estes aspectos foram abordados conforme a estrutura de cada ora, respeitando a linha de raciocínio do autor.

As análises, levadas a efeito, constatam que, por um lado, o tema Missões desperta interesses e incita a investigaçōes, por outro, o manuseio indevido de aspectos tão complexos o toma frágil e manipulável, conforme as intençōes de quem elabora. Isto se torna evidente no caso deste estudo. Se pretendêssemos elaborar um perfil da sociedade missioneira e seus membros, através das contribuiçōes dos autores analisados, teríamos um ponto em comum: os guarani parecem realmente ser estes selvagens, agressivos e indolentes, que viviam em estado de miséria, que tudo devem aos missionários. Estes, por sua vez, passam de diligentes homens, que tentam criar personalidade e individualismo nos indígenas, a ameaçadores padres que tentam construir um Império Teocrático, numa sociedade escravocrata. Ou então ainda, os articuladores de uma organização com princípios socialistas, em que predomina o humanitarismo, o coletivismo e a harmonia entre seus membros. Parece impossível uma mesma estrutura e organização social, durante um mesmo período histórico, comportar qualidades tão extremadas.

Talvez em poucas áreas científicas se encontre uma convivência até harmoniosa de correntes tão diferentes como na História. As abordagens aqui apresentadas são exemplos de correntes históricas que dão aos fatores ou uma interpretação espiritualista, ou tradicional tendendo ao nacionalismo, ou materialista. Mas, todas primam pelo idealismo de seus respectivos Ảutores, em relação aos fatos apresentados. Ou seja, procuram contar a história tal como gostariam que fosse.

A análise sobre os artigos do Pe. Teschauer revela dados importantes a serem considerados num levantamento historiográfico. Como historiador, o Autor se apresenta coerente, contribuindo em inúmeros aspectos para a compreensão e esclarecimento do processo histórico. Entretanto, sua análise peca pela passionalidade etnocêntrica e subjetivismo, ao tentar salvaguardar a Companhia de Jesus de acusações recebidas. Por este aspecto em particular, sua obra não deve ser ignorada. Cabe ao pesquisador resgatar as informaçōes pertinentes e descartar aquelas em que está clara a tendência espiritualista 
de louvores e enaltecimento à Companhia de Jesus e seus membros. Seria praticamente impossível pretender, numa aventura metafísica, reconstruir o passado missioneiro, desprezando depoimentos e obras de autores jesuítas, uma vez que eles se constituem em grande parte das fontes escritas. Mas, por outro fundo, a fundação exclusiva e a-crítica de dados e interpretações por eles apresentadas, implicaria numa mera transcrição e numa perpetuação simplória de uma História a serviço de uma causa, que em pouco ou nada contribuiria para o progresso do conhecimento do passado.

Já a obra de Moysés Vellinho, o caso é mais sério. Numa tentativa de abordar a "totalidade" de um período histórico complexo, o Autor elabora um discurso contraditório, com profundas distorções factuais, visando comprovar a integração do Rio Grande do Sul ao Império Lusitano. Numa construçāo nacionalista e com clara inversão do processo histórico, nega o papel e a função dos Povoados missioneiros, como primeiro núcleo de colonização, atribuindo-lhes o objetivo de usurpadores dos domínios coloniais portugueses. A opropriação da História, por Moysés Vellinho, contribui de uma forma polêmica para a historiografia do Rio Grande do Sul, e em especial das Missões. Suas afirmações subjetivas, sua desconsideração às fontes documentais e suas distorcidas interpretações, incitam o historiador a desmitificar e reescrever coerentemente e con-provar os absurdos ali registrados.

Por último, tem-se a obra de Décio Freitas. Como um "aprendiz-de-feiticeiro imaturo", Décio Freitas reúne as categorias de análise do materialismo histórico, e procura identificar no caso das Missōes uma primeira manifestação de socialismo no Brasil. Numa elaboração político-ideológica busca, no sistema missioneiro, um exemplo a ser seguido na atualidade, utilizando-se da História de uma forma panfletária.

O saldo das análises realizadas indica uma certa vulnerabilidade da História, que permite qualquer pessoa arbitrar-se o direito de escrever sobre o passado e construir seu modelo de interpretação, utilizando-se dos recursos teóricos que lhe convém e não o que as especificidades do caso exigem. Se por um lado, isto pode diminuir as características científicas do campo de investigação da História, por outro, exige a produção de historiadores e especialistas para que não permaneçam os mitos criados. Acredita-se que, quando pessoas se dedicam seriamente a aprofundar as pesquisas em fontes materiais e documentais, quando se dispöem a rever teorias e a 
elaborar modelos condizentes com o substrato histórico estudado, pode-se esperar o crescimento de conhecimentos e avaliar a contínua construção da História enquanto ciência. Doravante também não deve iludir-se com a proposta de que o ato de reescrever História parta da premissa de cobrir com um "manto de cientificidade" um outro "tipo ideal" de historiografia missioneira. A crítica à passionalidade e o subjetivismo de alguns autores, a abordagem de novos dados e as novas interpretaçōes devem estar pautados pelos limites e possibilidades da reconstrução de uma realidade já inexistente e perpetuada, em grande parte, de forma parcial.

\section{NOTAS}

${ }^{1}$ NICOLAI, André. Comportamento econômico e estruturas sociais. São Paulo, USP, 1973, p.58 e 62 .

2KERN, Amo A. "Problemas teórico-metodológicos relativos à análise do processo histórico missioneiro". In: Anais do VI Simpósio Nacional de Estudos Missioneiros (Santa Rosa): 27-42, out. 1985.

${ }^{3}$ Id., ibidem, p.12.

4I., ibidem, p.13.

5TESCHAUER, Carlos (S.J.). Porandúba Riograndense. Porto Alegre, Globo, 1929.

O termo significa inquiriçäo, notícia, relaçảo (do verbo tupi "morandub"). Op. cit., p.5.

Os capítulos analisados são: Cap. V: “As Missōes Orientaes” (p.172-181); Cap. VI: "O Caracter canonico das reduçōes no Rio Grande do Sul” (p.182-193); Cap. VIII: “Civilizaçāo dos Guaranis no Rio Grande do Sul (237-270).

6Id., ibidem, p.182-3. Nas citaçōes será respeitada a grafia origial.

${ }^{7}$ MELIÁ, Bartomeu. El Guarani conquistado y reducido. Asunción, Centro de Estudios Antropológicos, 1986, p.188 e segs.

${ }^{8}$ Id., ibidem. RUIZ DE MONTOYA, Antonio (S.J.). Conquista espiritual feita pelos religiosos da Companhia de Jesus nas Provtncias do Paraguai, Paraná, Uruguai e Tape. Porto Alegre, Martins Livreiro, 1985, p.34.

${ }^{9}$ TESCHAUER, Carlos. Op. cit., p.240.

10 $1 d_{\text {. }}$, ibidem.

${ }^{11}$ Id., ibidem, p.239.

12 Id., ibidem, p.237-8.

13 Id., ibidem, p.238-9.

14Id., ibidem, p.242. 


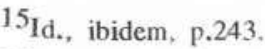

16Id., ibidem, p.248.

17 KERN, Arno A. Op. cit., p. 10.

${ }^{18}$ Id., ibidem.

${ }^{19}$ Id., ibidem.

${ }^{20}$ Id., ibidem, p.251.

${ }^{21}$ Vellinho, Moysés. Capitania d'El Rei. Porto Alegre, Globo, 2.ed., 1970.

22 POPPER, Karl. A lógica das Ciências Sociais. Rio de Janeiro, Tempo Brasileiro, 1978, p.16 e 27-8. Citado e ampliado por KERN, Arno A. Op. cit., p.213.

${ }^{23}$ VELLINHO, Moysés. Op. cit., p.53.

${ }^{24}$ Id., ibidem, p.28.

25 Id., ibidem, p.29-30.

26Id., ibidem, p.30.

${ }^{27}$ Id., ibidem, p.31.

${ }^{28}$ Id., ibidem, p.33.

${ }^{29}$ Id., ibidem, p.51.

30Id., ibidem, p.54.

${ }^{31}$ CORTESÃO, Jaime. Raposo Tavares e a formação territorial do Brasil. Rio de Janeiro, Ministério da Educaçāo e Cultural, 1958, p.128. In: VELLINHO, Moysés. Op. cit., p.52.

32 VELLINHO, Moysés. Op. cit., p.54.

${ }^{33}$ KERN, Arno A. "O processo histórico platino no século XVI: da Aldeia Guarani ao Povoado Missioneiro". Estudos Ibero-Americanos, Porto Alegre, PUCRS, XI (1): 23-41, 1985, p.29.

${ }^{34}$ VELLINHO, Moysés. Op. cit., p.57.

35Id., ibidem, p.66-8.

36Id., ibidem, p.79.

${ }^{37}$ Id., ibidem, p.80.

${ }^{38}$ Id., ibidem, p.71.

${ }^{39}$ Id., ibidem.

40 Id., ibidem, p. 80.

${ }^{41}$ Id., ibidem, p.83.

42 Id., ibidem, p.81-2 e 84 .

${ }^{43}$ Id., ibidem, p.82.

${ }^{44}$ KERN, Arno A. Op. cit., p.37; 1985.

${ }^{45}$ VELLINHO, Moysés. Op. cit., p.94-5 e 96.

${ }^{46}$ VILAR, Pierre. "História marxista, história em construção". In: História: novos problemas. Rio de Janeiro, Liv. Francisco Alves, 1976, p.164.

${ }^{47}$ Id., ibidem, p.175. 
48Freit AS, Décio. O socialismo missioneiro. Porto Alegre, Movimento, 1982. p. 14 .

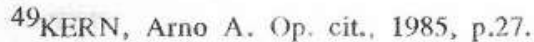

$50 \mathrm{O}$ autor nāo indica, durante o texto, a correta relação afirmação/citação/fonte Somente no final da obra, faz uma relação da bibliografia e fontes constiltadas. o que dificulta qualquer tentativa de comprovaçâo.

${ }^{51}$ FREITAS, Décio. Op. cit., p. 30.

52 KERN, Arno A. Op. Cit., 1985, p.32. Para uma análise mais abrangente sobre a economia guarani - SOUZA, José Otávio C. Uma introduçâo ao sistema técnico-econômico guarani. Dissertaçâo Mestrado, UFRGS, 1987.

${ }^{53}$ FreITAS, Déćio. Op. cit., p.30

${ }^{54}$ Id., ibidem, p.29.

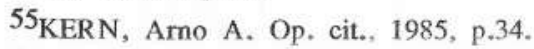

56FREITAS, Décio. Op. cit. p. 30.

57 Id., ibidem, p. 32 .

58 Id., ibidem.

${ }^{59}$ Id, ibidem, p.33.

${ }^{60}$ Id, ibidem.

${ }^{61}$ Id., ibidem, p. 35 .

${ }^{62}$ Id., ibidem, p.33-35.

${ }^{63}$ Id., ibidem, p.34-5.

${ }^{64}$ Id., ibidem, p. 35 .

${ }^{65}$ Id., ibidem, p.59.

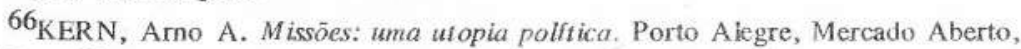
1982, p.74.

${ }^{67}$ FREITAS, Décio. Op. cit., p.44-56.

${ }^{68}$ Id., ibidem, p.59.

${ }^{69}$ VILAR, Pierre. Op. cit., p.173.

${ }^{*}$ Pontifícia Universidade Católica do Rio Grande do Sul Departamento de História

CEP - 90.620 - Porto Alegre - RS 